the relatives of the patient, and Mr. Edmund Owen's paper was an excellent effort to get people to abandon that position.

I hope Sir George Beatson will give us some assistance by answering some of my queries, and I hope also that he will pardon me when $I$ add a few questions at the end of this rather long letter. I am quite open to conviction, and it is for Sir George Beatson and others who attack our present position to prove us in the wrong; but they must do so by figures and reasons, not by merely stating that we are blind. My questions are these :-

1. Sir George Beatson says that he is satisfied with the results obtained in 300 cases. What are the results? He does not say.

2. 300 cases seems a large number at first sight, but with Sir George Beatson's experience I should have expected a larger number, especially when surgeons considerably junior quote from double this number. Were all these 300 acute cases?

3. Was any "selective action" exercised either by Sir George Beatson or by those responsible for the admission of cases? What I mean is this, Do these figures comprise all the cases admitted consecutively on Sir George Beatson's taking-in days in all stages of the disease, or do any cases admitted on those days go under other surgeons?

4. Under what circumstances and at what stage does Sir George Beatson operate? What are the results obtained in those cases which are operated upon?

5. Sir George Beatson says he is satisfied with his results, and it may be that he has good reason for his satisfaction, in which case he will no doubt have made a number of converts among his colleagues, or perhaps I should say that he will have impressed them with the value of ancient rites, so that they have not strayed after modern gods! Is this the case? I am, Sir, yours faithfully, W. H. Clayton-GREENE.

Devonshire-place, W., March 17th, 1913.

\section{WATER DIURESIS AND WATER RETENTION.}

To the Editor of THE LANCET.

Str,-I have been impressed by the fact that the daily ingestion of more or less considerable quantities of water, taken for the laudable purpose of flushing or washing out the system, is by no means always productive of good results. Indeed, in some instances the excess of liquid seems to determine an uncomfortable rise of blood pressure which is accounted for by the failure of its immediate objectviz., increased diuresis; in other words, the excess of water has not been eliminated, but has been retained and swells the general mass of blood.

Why some patients should be able to get rid of water rapidly while others only do so after the lapse of several mours is a question that had long been a puzzle to me. Thanks to the researches of Widal and his school, we are samiliar with chloride and urea retention, but the discovery of the possibility of water retention, apart from chloride retention, is a further and most important departure. Light bas of late been thrown on this subject, which is of great interest to spa practitioners, by the researches of Vaquez, Albarran, Widal, Merklen, and others, and as the matter comes within the scope of daily experience in mineral water resorts I propose briefly to discuss these results and their bearings on treatment

In the normal healthy individual the amount of urine excreted is markedly and immediately influenced by the intake of liquid, any excess being promptly got rid of by more copious emission. Albarran has drawn attention to the fnteresting clinical fact that in presence of renal disease the excretion of excess water is delayed; in other words, the damaged kidney excretes water as best it can, and is unable to regulate its working function to meet an excessive intake of fluid. This explains why it is that the subjects of renal trouble require to pass water several times during the nightriz., that they are working off the accumulations of the day. "'here are certain other peculiarities to be noted in this connexion. Under ordinary circumstances more urine is secreted lying down than walking about, but in the normal healthy man the heightening of the blood pressure due to physical and mental exertion corrects this tendency, so that more water is passed in the daytime than by night, and the night urine is darker in colour and of a higher specific gravity than the day urine.

In cardiac subjects with a tendency to asystole, on the other hand, the much greater facility with which urine is secreted when the patiert is lying down, as compared with the output when up and about, is very striking and possesses a certain diagnostic importance. In a case mentioned by Merklen the secretion was 254 c.c. lying down and only 86 c.c. when up-the so-called cardiac rhythm. In certain forms of nephritis, however, there is a curious tendency to equalisation of urinary secretion with possibly a balance in favour of the erect position-orthostatism; for instance, 98 c.c. an hour when up and only 84 c.c. in bed, so that the natural tendency is reversed. This, again, possesses considerable clinical significance, especially as it is associated, says Vaquez, with a reversal of the normal condition of things, in that the day urine is not only scanty but is dark in colour, while that passed at night is watery. In presence of this abnormal urinary rhythm, however, before we incriminate the kidney, we must make sure that the disturbance is not due to mechanical-that is to say extra-renal-causes. It is obvious that any delay in the absorption of ingested liquid, as, for instance, in dilated stomach, congestion of, or degenerative changes in, the liver, and an enfeebled circulation consequent upon cardiac weakness or disease, will lead to a deficient supply of liquid to the kidney and consequently to delayed excretion, even in the absence of any imperfection on the part of the renal filter. For mechanical reasons this deficiency is most marked during the daytime ; consequently the cardiac or extra-renal subject exhibits this tendency to exaggerated secretion in the recumbent position in a marked degree. It is, however, only because he is up and about all day that he excretes so much at night. If he passes much time on his back during the daytime the difference will not be so noticeable; hence, on admission to hospital this disturbance of rhythm often clears up altogether. No such effect is produced by change of posture in the subject of renal impermeability, since in his case the delay in the excretion of water is due merely to the inability of the kidney to afford it passage. The liquid taken during the daytime cannot be got rid of until the arterial tension rises high enough to force a passage, and this takes some eight or ten hours; consequently it is passed during the hours of darkness.

Vaquez has devised and carried out an ingenious, albeit simple, method of testing renal permeability to water, the results of which cannot fail to modify current views on mineral water cures and impose more discrimination in their application. These results may be summed up as follows. In the normal state the kidney responds to the demand for increased functional activity by promptly getting rid of the experimental water (600 c.c. taken fasting in the morning), elimination taking place slightly more rapidly lying down than standing up. In presence of extra-renal factors that hinder elimination the delay is well marked so long as the patient is up and about, but disappears when he lies down. This is the so-called cardiac rhythm. In renal cases artificial -i.e., experimental-polyuria does not take place, the secretion of urine not undergoing any increase during the hours that follow the experimental ingestion of water and not being got rid of until, further ingestion having ceased when the patient retires to rest, the surplus is gradually worked off. Here the results are the same whether the patient be erect or recumbent. It follows that drinking large quantities of liquid is not necessarily followed by copious diuresis, and when the excess of water is not thus disposed of it accumulates in the organism, raising arterial pressure and giving rise to various circulatory disturbances. Clinical experience shows that there are eonditions in which the quantity of liquid should be reduced, some indeed in which it must be strictly measured.

In chronic affections - gravel, gastro-intestinal atony, renal and hepatic insufficiency and auto-intoxications--therapeutical diuresis is indicated, and if by such means we can secure the passage of a large amount of clear urine the circulatory symptoms will subside. According to Professor Arnozan the best plan in mild cases is to give sereral tumblers of mineral water in the morning on an emptr stomach, to be followed by a walk, but if experimental diuresis shows a reversal of the orthostatic formula, that is to say, if the urinary secretion lying down takes place with 
the same rapidity as in the normal subject when taking exercise, the patient should only take small quantities of water in the morning and remain lying down. Subjects in whom water fails to determine any diuretic effects will do better on a dry regimen, but the desired action in these cases can sometimes be obtained by substituting carbohydrates for nitrogenous articles of food.

It is to be noted that renal lesions merely cause delay in the excretion of fluids which, as is also the case with urea, are not retained in the tissues, but accumulate in the blood and are gradually got rid of when the arterial tension rises to the necessary height under the influence of the retention. Water retention and œdema, as a rule, only take place in presence of chloride retention, but the delay in getting rid of liquids is sufficient to cause considerable disturbance of the circulation which in these subjects is already in an unsatisfactory state. There are, however, cases in which delay in the excretion of fluids is the only perceptible anomaly, and this isolated symptom often constitutes a pre. monitory sign of the renal lesion enabling us to intervene before it goes farther. As Vaquez points out, when, in addition to the delay in the excretion of fluids, there is more or less chloride and nitrogenous retention, it is even so a matter of extreme importance to determine the degree of impermeability to fluids in order to know what part it plays in the production of the symptoms and to regulate the diet of the patient accordingly.

\section{I am, Sir, yours faithfully}

AlfFred S. GuBb, M.D. Paris,

Consulting Physician at Aix-les-Bains, Savoie.

Mustapha Supérieur, Alger.

\section{BREAD AND THE SPREAD OF TUBERCULOSIS.}

\section{To the Editor of THE LANCET.}

SIR,-In paragraph 13 of the Final Report of the Tuberculosis Committee it is stated that " the principal classes of food in which those (i.e., tubercle) bacilli are at present found are meat, milk, and milk products." No mention is made of bread. It would be interesting to know if any investigations into bread as a source of conveyance of tubercle bacilli have been carried out, and, if so, with what result. The press has lately given us some insight into the methods and conditions of small bakehouses, and if their accounts are true there seems to be here a possible source of infection of scarcely less magnitude than in the case of milk the more so as the bacilli would in the case of bread be of the human type. In any event, greater supervision of these places is desirable even if we are not prepared to abolish bakeries where bread is hand-made.

I am, Sir, yours faithfully,

ARThUR H. Priestley, M.B. Tict.

Norwich. March 14th, 1913.

\section{A QUESTION IN LUNACY CERTIFICATION. To the Editor of THE LANCET.}

SIR,-In Dr. Robert Jones's letter under this heading in your last issue, a statement occurs that reception orders signed by justices not specially appointed will be invalid unless countersigned by a justice who is specially appointed. Allow me to point out that they are valid and accepted by the Lunacy Commissioners, vide Lunacy Act, 1891, Sect. 24 (3), and patients can be and are often admitted on such orders and kept for 14 days from the date of the order, and after that, if before the 14 days elapse, the order is approved and signed by a judicial authority.

This is a great convenience in the provinces, where the specially appointed justices are not so well known as they appear to be in London, and it might take a considerable time to find out whether a justice happened to be specially appointed or not, and in urgent cases time is a great consideration.

I have known cases where specially appointed justices did not know that they were specially appointed, and often those who know it fail to add the statement of their being appointed to their description, which omission causes the Commissioners in Lunacy to send back the order, and then the medical officer who has received the patient has to either get the statement added and initialled by the writer, or the order signed by some other judicial authority. Practically any J.P. can sign a reception order which can be acted upon. 1 am, Sir, yours faithfully,

L. HARRIS-LISTON.

Middleton St. George, co. Durham, March 17th, 1913.

\section{THE THERAPEUTIC ACTION OF SPLENIC EXTRACT.}

To the Editor of THE LANCET.

SIR, - In THE LANCET of Feb. 22nd Dr. Henry R. Harrower brought evidence to the efficiensy of splenic extract in tuberculosis, typhoid, and malaria. He states : "It is a valuable remedy for the treatment of those conditions in which malnutrition is an important factor." Dr. Harrower, however, did not take into consideration the action of spleen extract (hormonal) as a powerful peristaltic stimulant, as demonstrated and proved clinically by Zoelzer, who used it in cases of chronic constipation. Zoelzer states that it is given in doses of 20 c.c. as hypodermic or intravenous injection. Might not its digestive action, as shown by Dr. Harrower, combined with its peristaltic action, so help assimilation and rest the digestive organs that its sole efficiency could be attributed to this phase and not to any other obscure effects? I am, Sir, yours faithfully,

KRIKOR S, KRIKORIAN.

School of Medicine, American University, Beirut, March 6th, 1913.

\section{THE VITAL STATISTICS OF LONDON. To the Editor of THE LANCET.}

SIR, - I am unable to understand how, in your article on the Vital Statistics of London, you can refer to the fall in the birth-rate as " a fact which can only be regarded as serious, whatever interpretation be put upon it." For, as you say further on, "we find that the death-rate of Iondon has declined from 24.4 in the $1861-1870$ decade to 15 in 1911 , the lowered death-rate compensating for the lowered birthrate." When a falling birth-rate is thus accompanied by a correspondingly falling death-rate-and statistics show that this is almost invariably the case-why deplore it ? And why speak of Shoreditch as occupying "pride of place" among the metropolitan boroughs, when later you have to add that it "had the highest death-rate as well as the highest birth-rate"? Do statistics not generally show that high birth-rates mean high death-rates?

I am, Sir, yours faithfully,

Binnie Dunlop, M.B., Ch.B. Glasg-

Alexandra Court, S.W., March 15th, 1913.

\section{THE PHARMACOLOGY OF FOOD.}

\section{To the Editor of THE LANCET.}

SIR, - The isolation of a definite substance in minute quantity from certain foods, the assimilability or nutritive value of which depends upon this substance, looks as though the sound study of dietetics will have in future to be based in part on pharmacology. This seems, at any rate, to be the teaching of recent experiments. It is evident, for example, that when it is shown that an artifieial mixture fails to feed satisfactorily in spite of its containing all classes of nutritive material known to us as proteins, fats, carbohydrates, and mineral salts, there is somewhere an overlooked factor the coöperation of which is essential to healthy nutrition and growth. The case of beri-beri is to the point, where it has been shown to the satisfaction of most of us that the disease is due to malnutrition arising from the consumption of polished rice. The "polishings" contain a nucleic substance, and the administration of this substance or the polishings themselves restore the animal to normal health. But it is not only in rice that this peculiar substance occurs, and therefore it is probable that disturbances in health may arise from a similar deficiency of nucleic substance in other foods. It is remarkable, at any rate, that it is present in the germ of the wheat, in meat, milk, egos, the buds of vegetables, yeast, bran, and lime juice. The use of the last-named substance in scurvy is well known, and recently a nucleic principle has been recovered from lime juice which was found to cure avian polyneuritis.

This is important. With the constant occurrence of this vital substance in many foods the general consumer's chance 